\title{
INDEX TO Volume 29 (2011)
}

\section{Articles}

BRACHER, Nathan. Timely Meditations on the Use and Abuse of History: Léon Werth's Déposition. Journal de guerre 1940-1944 (Vol. 29, No. 2, 115)

CHOI, Sung. The Muslim Veteran in Postcolonial France: The Politics of the Integration of Harkis After 1962 (Vol. 29, No. 1, 24)

DROTT, Eric. The nòva cançon occitana and the Internal Colonialism Thesis (Vol. 29, No. 1, 1)

FAYARD, Nicole and ROCHERON, Yvette. "Moi quand on dit qu'une femme ment, eh bien, elle ment": The Administration of Rape in Twenty-First Century France and England \& Wales (Vol. 29, No. 1, 68)

GUNTHER, Scott. A New Identity for Old Europe: How and Why the French Imagined Françallemagne in Recent Years (Vol. 29, No. 1, 46)

\section{EvenTS AND Debates}

TARROW, Sidney. "Red of Tooth and Claw": The French Revolution and the Political Process-Then and Now (Vol. 29, No. 1, 93)

\section{Special Issue on Europe Union: Are the Founding Ideas Obsolete?}

BURGESS, Michael. Entering the Path of Transformation in Europe: The Federal Legacy of the Schuman Declaration (Vol. 29, No. 2, 4)

CHOPIN, Thierry. Après Lisbonne, quelles perspectives pour la relation transatlantique? (Vol. 29, No. 2, 105)

MALLARD, Grégoire and FOUCAULT, Martial. The Fractal Process of European Integration: A Formal Theory of Recursivity in the Field of European Security (Vol. 29, No. 2, 68)

OPPELN, Sabine von. Les soubresauts du couple franco-allemand: moteur ou frein de l'intégration européenne? (Vol. 29, No. 2, 55)

PETIT, Isabelle and ROSS, George. Introduction (Vol. 29, No. 2, 1)

PETIT, Isabelle. L'UE du vingt-et-unième siècle: La fin des idéaux fédéralistes des Pères fondateurs? (Vol. 29, No. 2, 19)

ROSS, George. The Revenge of Neglected Issues: The EU Founders' and Social Policy (Vol. 29, No. 2, 90)

TOULEMON, Robert. France-Allemagne: Noces de diamant ou chronique d'un divorce annoncé ? (Vol. 29, No. 2, 42) 


\section{Special Issue on Political Radicalism in France: Changing Paradigms}

ANCELOVICI, Marcos. In Search of Lost Radicalism: The Hot Autumn of 2010 and the Transformation of Labor Contention in France (Vol. 29, No. 3, 121)

COLE, Alistair. The French Socialist Party and its Radical Ambiguity (Vol. 29, No. 3, 29)

EVANS, Jocelyn. Political Radicalism, Policy Expectation, and Electoral Competition in France: A Means to the End? (Vol. 29, No. 3, 12)

GRUNBERG, Gérard. Le radicalisme dans le parti socialiste aujourd'hui (Vol. 29, No. $3,49)$

HAEGEL, Florence. Nicolas Sarkozy a-t-il radicalisé la droite française? Changements idéologiques et étiquetages politiques (Vol. 29, No. 3, 62)

MAYER, Nonna.Why Extremes Don't Meet: Le Pen and Besancenot Voters in the 2007 French Presidential Election (Vol. 29, No. 3, 101)

SHIELDS, James. Political Radicalism in France: Perspectives on a Protean Concept (Vol. 29, No. 3, 1)

SHIELDS, James. Radical or Not So Radical? Tactical Variation in Core Policy Formation by the Front National (Vol. 29, No. 3, 78)

\section{Review Essays}

DESAN, Suzanne. Internationalizing the French Revolution (Vol. 29, No. 2, 137)

HOWORTH, Jolyon. France and the Unification of Germany: Clio's Verdict? (Vol. 29, No. 1,118$)$

LADENSON, Elisabeth. Beauvoirology (Vol. 29, No. 1, 111)

\section{Book Reviews}

BENSON, Rodney. Turning on the Mind: French Philosophers on Television by Tamara Chaplin (Vol. 29, No. 1, 142)

BOHLING, Joseph. La Lutte antialcoolique en France depuis le XIX $X^{e}$ siècle by Bertrand Dargelos (Vol. 29, No. 3, 141)

CAMISCIOLI, Elisa. La Condition noire: Essai sur une minorité française by Pap Ndiaye (Vol. 29, No. 1, 145)

CHARNOW, Sally Debra. Théâtres en capitales: Naissance de la société du spectacle à Paris, Berlin, Londres et Vienne, 1860-1914 by Christophe Charle (Vol. 29, No. 3, 145)

DUTTON, Paul V. Breadwinners and Citizens: Gender in the Making of the French Social Model by Laura Levine Frader (Vol. 29, No. 1, 134)

JANKOWSKI , Paul. The Hunt for Nazi Spies: Fighting Espionage in Vichy France by Simon Kitson (Vol. 29, No. 1, 137)

KRAMER, Lloyd. Liberal Values: Benjamin Constant and the Politics of Religion by Helena Rosenblatt (Vol. 29, No. 1, 130)

LECLER, Romain. The New Face of Political Cinema: Commitment in French Film since 1995 by Martin O'Shaughnessy (Vol. 29, No. 3, 155)

NORD, Philip. In Pursuit of the People: Political Culture in France, 1934-39 by Jessica Wardhaugh (Vol. 29, No. 3, 149)

PLAZA, Arthur. Mobilizing Youth: Communists and Catholics in Interwar France by Susan B. Whitney (Vol. 29, No. 3, 152) 
ROGERS, Susan Carol. The Life of Property: House, Family and Inheritance in Bearn, South-West France by Timothy Jenkins (Vol. 29, No. 1, 149)

TAYLOR, Lynne. The Politics of Everyday Life in Vichy France: Foreigners, Undesirables, and Strangers by Shannon Fogg (Vol. 29, No. 1, 139)

\section{INDEX OF BOOKS REVIEWED}

CHAPLIN, Tamara. Turning on the Mind: French Philosophers on Television reviewed by Rodney Benson (Vol. 29, No. 1, 142)

CHARLE, Christophe. Théâtres en capitales: Naissance de la société du spectacle à Paris, Berlin, Londres et Vienne, 1860-1914 reviewed by Sally Debra Charnow (Vol. 29, No. $3,145)$

DARGELOS, Bertrand. La Lutte antialcoolique en France depuis le XIX ${ }^{e}$ siècle reviewed by Joseph Bohling (Vol. 29, No. 3, 141)

FOGG, Shannon. The Politics of Everyday Life in Vichy France: Foreigners, Undesirables, and Strangers reviewed by Lynne Taylor (Vol. 29, No. 1, 139)

FRADER, Laura Levine. Breadwinners and Citizens: Gender in the Making of the French Social Model reviewed by Paul V. Dutton (Vol. 29, No. 1, 134)

JENKINS, Timothy. The Life of Property: House, Family and Inheritance in Bearn, SouthWest France reviewed by Susan Carol Rogers (Vol. 29, No. 1, 149)

KITSON, Simon. The Hunt for Nazi Spies: Fighting Espionage in Vichy France reviewed by Paul Jankowski (Vol. 29, No. 1, 137)

NDIAYE, Pap. La Condition noire: Essai sur une minorité française reviewed by Elisa Camiscioli (Vol. 29, No. 1, 145)

O'SHAUGHNESSY, Martin. The New Face of Political Cinema: Commitment in French Film since 1995 reviewed by Romain Lecler (Vol. 29, No. 3, 155)

ROSENBLATT, Helena. Liberal Values: Benjamin Constant and the Politics of Religion reviewed by Lloyd Kramer (Vol. 29, No. 1, 130)

WARDHAUGH, Jessica. In Pursuit of the People: Political Culture in France, 1934-39 reviewed by Philip Nord (Vol. 29, No. 3, 149)

WHITNEY, Susan B. Mobilizing Youth: Communists and Catholics in Interwar France reviewed by Arthur Plaza (Vol. 29, No. 3, 152) 